\author{
N.K. Tanasheva ${ }^{2}$, A.N. Dyusembaeva ${ }^{1,2}$, B.R. Nussupbekov ${ }^{1}$, \\ L.L. Min'kov' ${ }^{3}$, Zh.G. Nurgalieva ${ }^{1}$, K.K. Sadenova ${ }^{1}$ \\ ${ }^{l}$ Ye.A. Buketov Karaganda State University, Kazakhstan; \\ ${ }^{2}$ Institute of Applied Mathematics, Karaganda, Kazakhstan; \\ ${ }^{3}$ Tomsk State University, Russia \\ (E-mail: nazgulya_tans@mail.ru)
}

\title{
The study of the aerodynamic coefficients of rotating cylinders
}

\begin{abstract}
In the course of the research, the theoretical knowledge on the aerodynamic characteristics of coiled cylinders in rotary motion was reviewed and the cylinders in circular motion on the working part of the aerodynamic pipe were studied. During the studying the dependence of the aerodynamic characteristics of rotating motion cylinders on the distance change, several cases of rotation of the cylinders were considered. When the direction of rotation of the cylinders changes, it is determined that frictional coefficient and the lifting force coefficient are changed. At the same time, the distance at which the aerodynamic parameters will have the highest value is determined. The rotation of rotating moving cylinders is determined by the aerodynamic pumps of the cylinders in the horizontal direction of the airflow due to the air velocity, the number of cylinders and the distance between the two cylinders. An increase in the velocity of the airflow is determined by the reduction of the coefficient of the friction coefficient and the lifting force of the cylinders in rotary motion; The aerodynamic characteristics of the coiled cylinders were first detected to increase the distance between the cylinders and reach them at a later distance. The aerodynamic characteristics of the cylinders with diameters $10 \mathrm{~cm}$ in diameter, that is the rotary motion, is determined by the maximum value with the coefficient of lifting force and the frontal impedance coefficient. These results are useful for us in practice, as these results can be used in smaller wind speed engines. In the local economy, the use of local wind power is a convenient, affordable, and environmentally friendly, with a minimal wind speed engine focused on reducing the deficit of electricity, which is one of the key issues in rural areas.
\end{abstract}

Keywords: rotary cylinders, magnus effect, angular barrier and lifting coefficients, Reynolds number.

\section{Introduction}

The main technical policy of the state for the further development of the energy sector is the launch of alternative energy sources. Kazakhstan is one of the countries with the alternative energy sources, such as water, wind, and solar energy. However, in addition to partial hydroenergy use, these alternative sources of power are not activated in the country. One of the main reasons for this is the fact that the country has a large concentration of energy resources.

Electricity can be divided into two: traditional and non-traditional. The most important source of traditional energy is coal, natural gas, peat and uranium. At first, the energy they have is coming from, but it is still an inexhaustible source of energy.

It's called irreversible because every year, only a small amount of solar energy becomes the energy of irreparable sources, and how many millions of years it takes to make a small amount of coal, ore, gas and uranium recovered. And non-traditional power sources include wind, water, solar energy, and so on. The use of renewable energy sources in energy consumption does not affect the overall heat balance here and does not lead to global warming. The energy coming from the ground and leaving the ground does not change. We take energy from the use of the newest generation of wind energy within this unhealthy electricity source. The first value of these sources of energy is that they do not harm nature. Renewable energy sources regularly replenish their energy and reaches millions of years until the wind reaches them. This is their second preferential.

The main importance of this research is to investigate the aerodynamic characteristics of the crankshafts' cylinders on the increase of power generation capacities of low-speed air flow motors. The wind speeds up to $4-5 \mathrm{~m} / \mathrm{s}$ in Karaganda. So far, low wind speed engines were identified with two shaft and three swing motors based on the Magnus effect. However, the electricity generated by them can not fully compensate for losses [1-5]. Therefore, in order to reduce the flow of these motor drives, we need to consider the mutually advantageous location of the blades, in particular the cylinders, which are their main mechanisms. 
Using our rotary motion cylinders, we set ourselves a goal to study how changes in their aerodynamic parameters affect the flow velocity, the number of cylinders, and the cylinder axes.

The main purpose of this research is to determine the effective location of the cylindrical blades, which relates to the basic elements of the wind turbines based on the Magnus Effect at low wind velocity and their dependence on other variables.

\section{Methods of research}

Research works at the aerodynamic pipeline are cheap and reliable. Therefore, the study of the aerodynamic patterns of the thing in the cylindrical form was carried out on the simple T-I-M aerodynamic pipe, located in the Aerodynamic measurement laboratory of the Department of Engineering Thermophysics named after professor Zh.S. Akylbayev. The aerodynamic pipe which is tested is an aerodynamic pipe with an open working zone in the closed circuit.

The coiled cylinders are located horizontally in the direction of air flow into the working part of the aerodynamic tube. For the study of the aerodynamic characteristics, lengths $31 \mathrm{~cm}$ are taken from $10 \mathrm{~cm}$ in diameter from two cylinders 3 and secured to bearing by means of the shaft 3 . A roller bearing is fitted to the rotary motion of the cylinder to prevent obstacle of friction force.

The cylinders are rotated by means of the electromotor 5 . In order to increase the rotation of the electromotor valve, it connects to the laboratory autotransformer with connecting wires. The rotary motion of one cylinder is supplied to the second cylinder by the belt pulleys 2 and the belt. Image of this mechanism is shown in Figure 1.

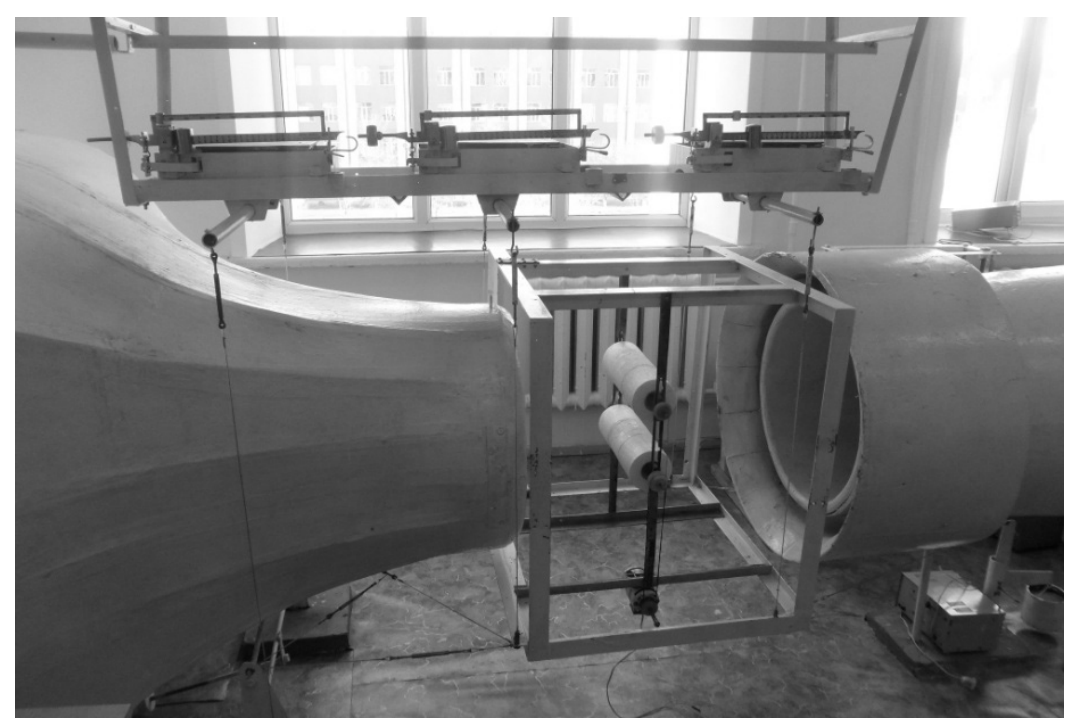

Figure 1. Figure of the workpiece video clip attached to the cylinders attached to the arrodynamic pipe

It is observed how the aerodynamic parameters of the cylinders change depending on the flow velocity, the rotation number and the distance between the two cylinders when the cylinders in the rotating motion are flowing horizontally. The results obtained from the experiments are as follows.

\section{Results of research}

Reduction of aerodynamic coefficients in speed of flowing air in a horizontal direction of cylinders with rotary motion is revealed in experiment.

The dependence of the barrier coefficient from the velocity of the airflow, i.e. the Reynolds number, is shown in Figure 2. 


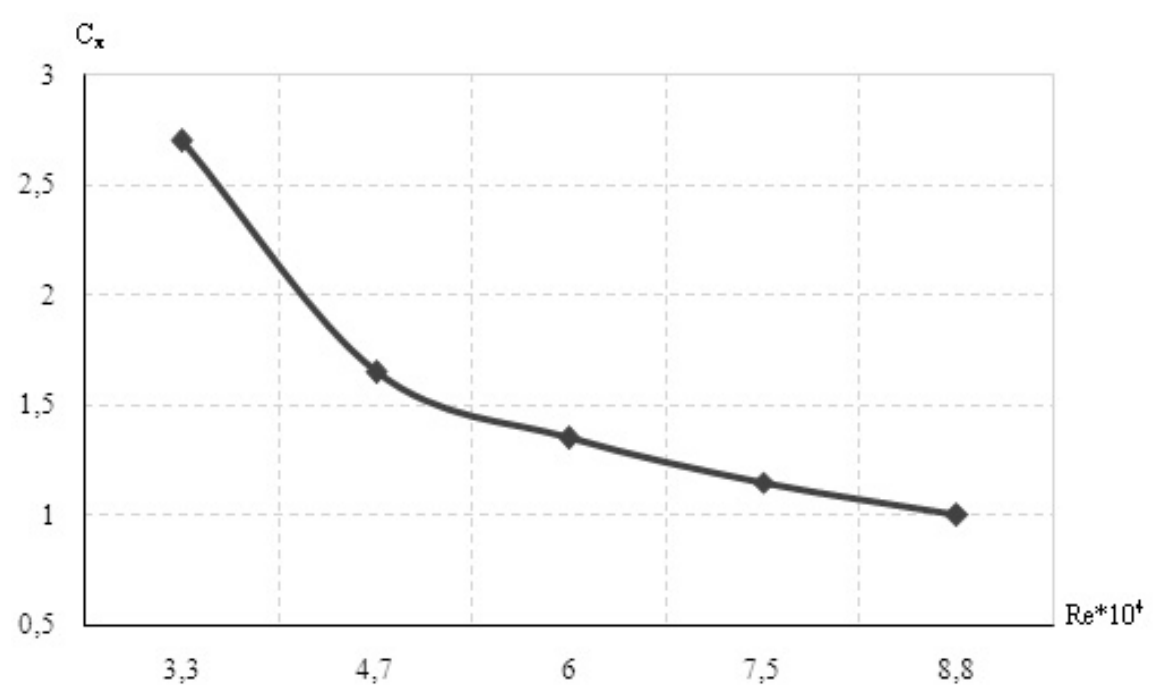

Figure 2. A graph of the Reynolds number dependence of the frontal barrier coefficient of cylinders with a diameter of $10 \mathrm{~cm}$ and $5 \mathrm{~cm}$ with a rotating moving distance when the engine is $120 \mathrm{~V}$

As you can see from the dependence, the coefficient of frictional resistance decreases as the value of Reynolds increases. If we recall the formula for the calculation of the coefficient of the angle barrier, then we see that the angle barrier is inversely proportional to the square of the velocity. In the equation, along with the velocity, the force of the angle barrier directly proportional to the coefficient varies. But its change is less than the square of speed. Therefore, the angular barrier coefficient decreases when the velocity of air flow increases.

Figure 3 illustrates the dependence of the lifting force coefficient of the cylinders with a diameter of $10 \mathrm{~cm}$ in distance of $5 \mathrm{~cm}$ in the constant rotation of the cylinder.

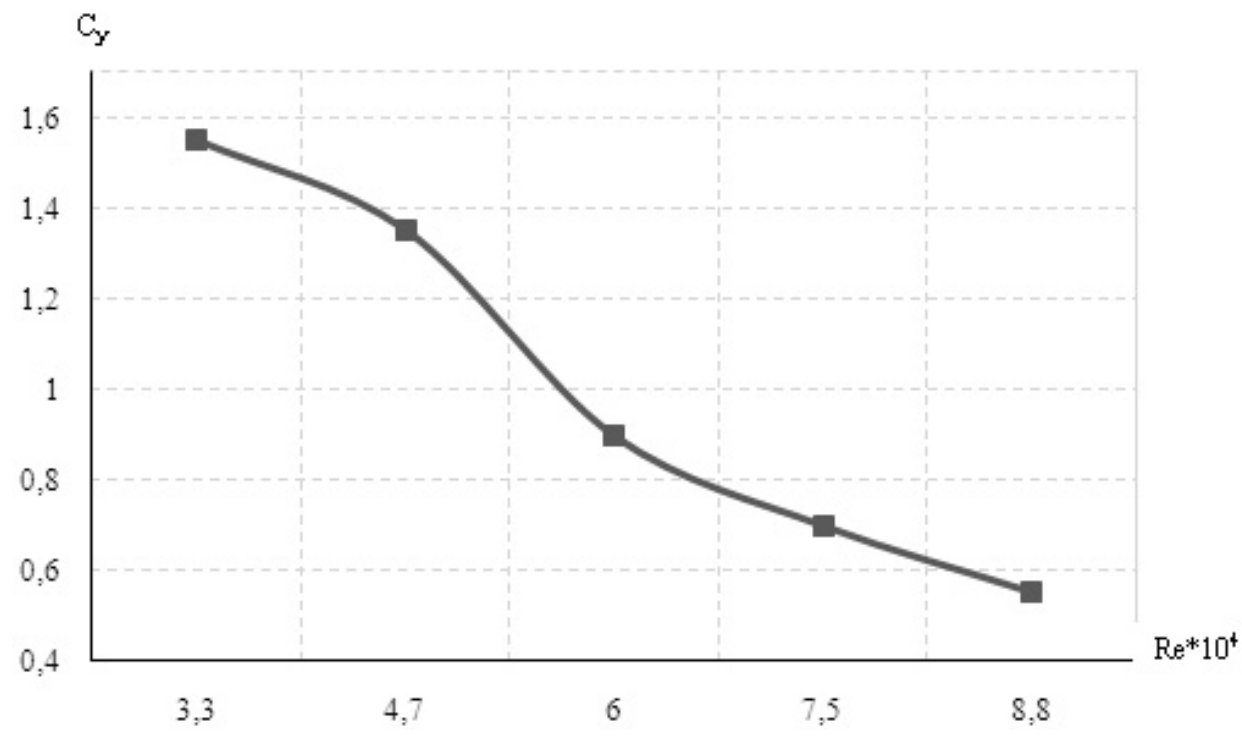

Figure 3. Dependence of lifting force on the Reynold number

As shown by the dependence on Figure 3, the lifting force of the double cylinders in rotating motion decreases as the number of Rheinolds increases. Because the lifting force is inversely proportional to the quadratic air velocity corresponds to the equation, and the Reynolds ratio is directly proportional to the velocity of the airflow, the lifting factor is proportional to the value of the Reynolds. Therefore, when the speed of the air flowing in the rotating motion of the cylinders in the orbital direction increases, the lifting force coefficient decreases.

The dependence of the friction coefficient of the rotating motion cylinders on the number of rotation of the cylinders is shown in Figure 4. 


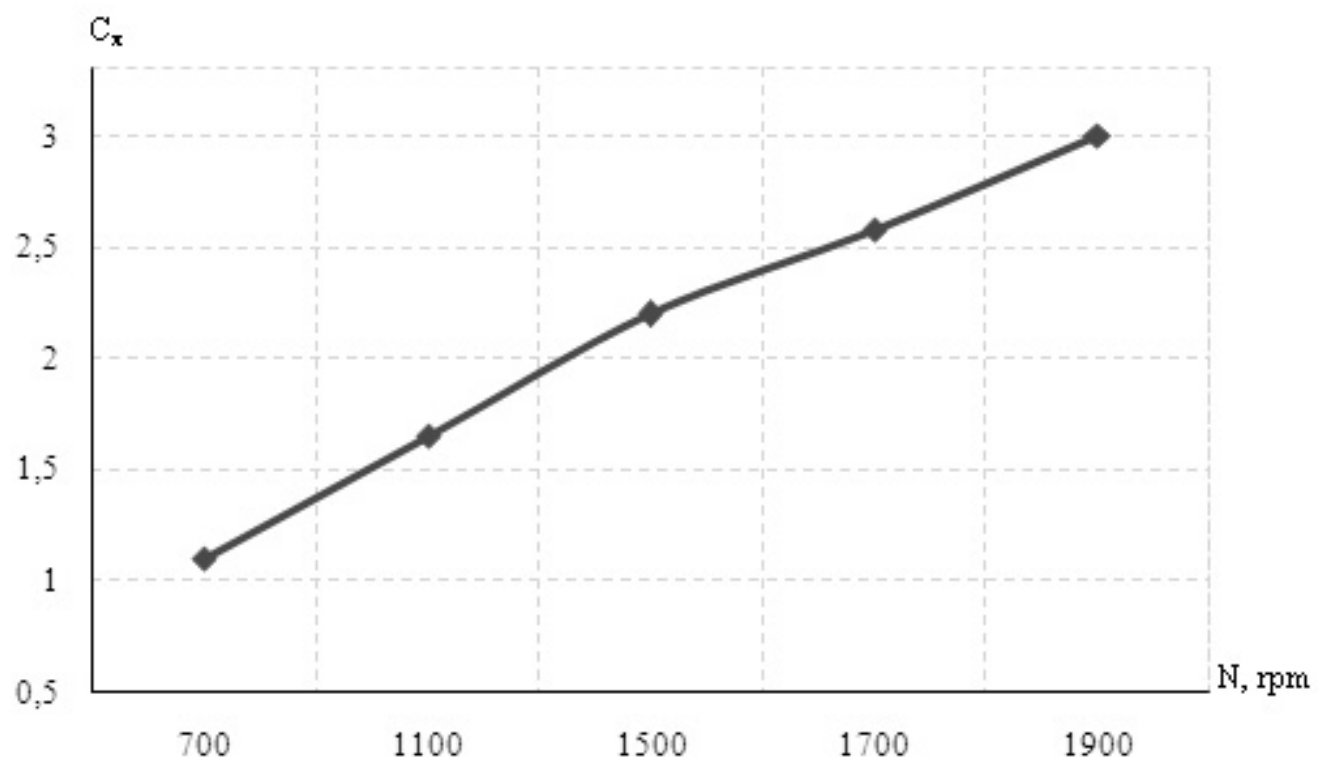

Figure 4. The dependence of the obstacle impedance on the number of rotations

As shown by the dependence, the angular barrier coefficient of rotating-acting cylinders with $10 \mathrm{~cm}$ in diameters $5 \mathrm{~cm}$ in distance horizontally oriented to the air flow varies directly proportionally to the number of rotation of the cylinders, i.e. the angle barrier coefficient increases as the number of rotations increases. The reason can be explained this way from a scientific point of view. At the back of the cylinders, the vortex area emerges when the air flows into the cylinder. Under the influence of these vortices, the pressure behind the cylinder decreases, the air rarely. When the rotating motion of the cylinder moves, the associated flow on the surface of the cylinder obstructs the movement of the incoming particles and starts to move them to the front surface of the cylinder. The air flows to the front of the cylinder under the influence of the direct flow. The energy of sealed air particles is greater than the energy of the absorbed air. As the number of cylinders revolves increasing, the compression of air particles on the front surface increases to a certain extent. This leads to the increased resistance of the cylinders. Therefore, when the number of rotation of the cylinders increases, the correlation coefficient also increases.

The following Figure 5 depicts the dependence of the cylinder rotation factor on the lifting force coefficient of rotating moving cylinders with a distence of $5 \mathrm{~cm}$ and a diameter of $10 \mathrm{~cm}$, horizontally positioned to the direction of the air flow of $7 \mathrm{~m} / \mathrm{s}$.

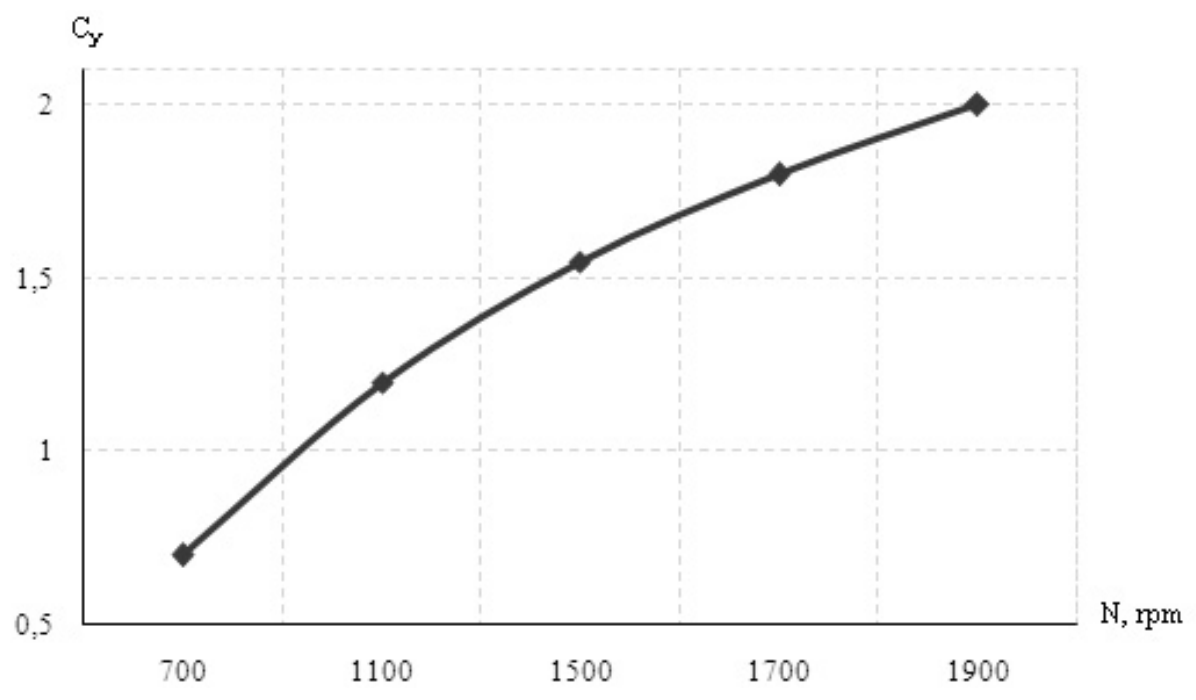

Figure 5. Graphs of dependence of the lifting force coefficient of cylinders with $10 \mathrm{~cm}$ in diameter of $10 \mathrm{~cm}$ with diameter of $5 \mathrm{~cm}$ with a velocity of $7 \mathrm{~m} / \mathrm{s}$ 
As you can see from Figure 5, the lifting force of the cylinders in rotary motion is decreasing with the increase in the number of cylinders. The reason for this is scientifically explained as follows. When the flow of rotating moving things flows horizontally, the magnesium effect is applied vertically to the cylinders, i.e. the reduced pressure zone is formed at the opposite direction to the air flow from the adjacent stream of the rotating cylinder on the surface of the rotating cylinder, and the associated flow to the upstream where there is an overpressure zone.

As a result, the cylinders move to the lower zone under the influence of forces in the high pressure zone. As the turnover increases, the force that affects the cylinders decreases in the reduced pressure zone and increases in the high pressure zone. Accordingly, the lifting force of the cylinders in the rotating motion increases. That is why the lifting force factor increases when the number of rotating cylinders increases.

\title{
Conclusion
}

The values obtained from the experiments can make a great contribution to increasing the power of the electric motors produced at low wind speeds. The results from the study of changes in the aerodynamic characteristics of the cylinders, especially between the cylinders that are blended, allow us to determine the effective location of the rotary cylinders, which are the main elements of the motor. The effective range of the spindle blades, that is, the cylinders, produces and consumes more electricity than the wind energy uses less energy. And with low cost and more energy-efficient engines, it is a good solution to reduce energy deficit in rural areas, far from central power plants.

This work was supported by project AP05131520.

\section{References}

1 Болотов А.В. Развитие ветроэнергетики Республики Казахстан, энергетические системы электроснабжения автономных объектов / А.В. Болотов, С.Е. Соколов, С.А. Болотов // Вестник АИЭС. - 2009. — № 3. - С. 11-18.

2 Бычков Н.М. Ветродвигатель с эффектом Магнуса. 2. Расчетные характеристики ветроколеса / Н.М. Бычков // Теплофизика и аэромеханика. - 2008. - Т. 15, № 2. - С. 583-596.

3 Kusaiynov K. Numerical simulation of a flow past a triangular sail-type blade of a wind generator using the ANSYS FLUENT software package / K. Kusaiynov, N.K. Tanasheva, L.L. Min'kov, B.R. Nusupbekov, Y.O. Stepanova, A.V. Rozhkova // Technical Physics. - 2016. - Vol. 61, Iss. 2. - P. 299-301.

4 Tanasheva, N.K. Effect of a rough surface on the aerodynamic characteristics of a two-bladed wind-powered engine with cylindrical blades / N.K. Tanasheva, T.O. Kunakbaev, A.N. Dyusembaeva, N.N. Shuyushbayeva, S.K. Damekova // Technical Physics. November 2017, Volume 62, Issue 11, pp 1631-1633.

5 Tanasheva N.K. Investigation of aerodynamic characteristics from the airflow angle of the rotating cylinder / N.K. Tanasheva, A.N. Dyusembaeva, L.L. Min'kov // Bulletin of the Karaganda University. Physics series. — 2018. — No. 1(89). - P. 88-92.

\author{
Н.К. Танашева, А.Н. Дюсембаева, Б.Р. Нусупбеков, \\ Л.Л. Миньков, Ж.Г. Нургалиева, К.К. Саденова
}

\section{Айналмалы қозғалыстағы цилиндрлердің аэродинамикалық коэффициенттерін зерттеу}

\begin{abstract}
Мақалада орындау барысында айналмалы қозғалыстағы қосақталған цилиндрлердің аэродинамикалық сипаттамалары тұралы теорияларға шолу жасалып, алынған теориялық білімдерге сүйене отырып, аэродинамикалық құбырдың жұмыстық бөлігінде айналмалы қозғалыстағы қосақталған цилиндрлер зерттелді. Айналмалы қозғалыстағы қосақталған цилиндрлердің аэродинамикалық сипаттамаларының арақашықтықтың өзгерісінен тәуелділігін зерттегенде цилиндрлердің айналу бағыттарының бірнеше жағдайы қарастырылды. Цилиндрлердің айналу бағыты өзгергенде олардың маңдайлық кедергі мен көтеру күші коэффициенттерінің өзгеретіндігі анықталды. Сонымен қатар аэродинамикалық параметрлер ең үлкен мәнге ие болатын арақашықтық белгілі болды. Айналмалы қозғалатын қосақталған цилиндрлерді ауа ағыны көлденең бағытта аққан кездегі цилиндрлердің аэродинамикалық сипаттамаларының ауа жылдамдығына, цилиндрлердің айналу санына және екі цилиндрдің арасындағы қашықтыққа байланысты өзгерісі анықталды. Ауа ағының жылдамдығы артқанда айналмалы қозғалыстағы қосақталған цилиндрлердің маңдайлық кедергі мен көтеру күші коэффициентерінің азаятындығы анықталды. Қосақталған цилиндрлердің аэродинамикалық сипаттамаларының, алдымен, цилиндрлердің арақашықтығы белгілі бір мәнге жеткенге дейін өсіп,
\end{abstract}


одан кейінгі арақашықтықтарда қайтадан кемитіндігі анықталды. Айналмалы қозғалыс жасайтын, диаметрлері 10 см қосақталған цилиндрлердің аэродинамикалық сипаттамалары, яғни көтеру күші және маңдайлық кедергі коэффициенттері ең үлкен мән қабылдайтын арақашықтық анықталды. Бұл нәтижелер тәжірибеде қолдануға пайдалы болып саналады, себебі оларды аз жел жылдамдығында жұмыс істейтін желқозғалтқыштарында қолдануға болады. Ал аз жел жылдамдығында жұмыс істейтін желқозғалтқышын ауылдық жерлердегі шешілмеген негізгі мәселелердің бірі болып есептелетін электр энергияның тапшылын азайту бағытында жергілікті шаруашылықта қолдану ыңғайлы, сонымен қатар экологиялық жағынан тиімді болып табылады.

Кілm сөздер: айнаймалы цилиндрлер, Магнус тиімділігі, көтеру күші және маңдайлық коэффициенттері, Рейнольдс саны.

\author{
Н.К. Танашева, А.Н. Дюсембаева, Б.Р. Нусупбеков, \\ Л.Л. Миньков, Ж.Г. Нургалиева, К.К. Саденова
}

\title{
Исследование аэродинамических коэффициентов вращающихся цилиндров
}

\begin{abstract}
Проведен обзор теоретических знаний об аэродинамических характеристиках спиральных цилиндров при вращательном движении и изучены цилиндры при круговом движении на рабочей части аэродинамической трубы. В ходе исследования рассмотрены зависимости аэродинамических характеристик цилиндров вращательного движения от изменения расстояния. При изменении направления вращения цилиндров определяется изменение коэффициентов трения и подъемной силы. Определены расстояния, на которых аэродинамические параметры имеют наибольшее значение. Вращение движущихся цилиндров определяется аэродинамическими насосами цилиндров в горизонтальном направлении воздушного потока за счет скорости воздуха, количества цилиндров и расстояния между двумя цилиндрами. Увеличение скорости воздушного потока определяется уменьшением коэффициента трения и подъемной силы цилиндров при вращательном движении; аэродинамические характеристики спиральных цилиндров были впервые обнаружены для увеличения расстояния между цилиндрами и достижения их на более позднем расстоянии. Аэродинамические характеристики цилиндров диаметром 10 см, т.е. вращательное движение, определяются максимальными значениями коэффициентов подъемной силы и лобового сопротивления. Эти результаты полезны на практике, так как они могут быть использованы для разработки двигателей, работающих при меньшей скорости ветра. В местной экономике использование ветроэнергетики является удобным, доступным и экологически чистым способом получения энергии. Двигатель ориентирован на снижение дефицита электроэнергии, что является одним из актуальных вопросов в сельской местности.
\end{abstract}

Ключевые слова: вращающиеся цилиндры, эффект Магнуса, коэффициенты лобового сопротивления и подъёмной силы, число Рейнольдса.

\section{References}

1 Bolotov, A.V., Sokolov, S.E., \& Bolotov, S.A. (2013). Razvitie vetroenerhetiki Respubliki Kazakhstan, enerheticheskie sistemy elektrosnabzheniia avtonomnykh obektov [Wind power development of Kazakhstan, energy power supply system of autonomous objects]. Vestnik AIES — Bulletin AIPET, 3(6), 11-18 [in Russian].

2 Bychkov, N.M. (2008). Vetrodvihatel s effektom Mahnusa. 2. Raschetnye kharakteristiki vetrokolesa [Wind turbine with Magnus. 2. Characteristics of the rotating cylinder]. Teplofizika i aeromekhanika - Thermophysics and Aeromechanics, 1, 583-596 [in Russian].

3 Kusaiynov, K., Tanasheva, N.K., Min'kov, L.L., Nusupbekov, B.R., Stepanova, Y.O., \& Rozhkova. A.V. (2016). Numerical simulation of a flow past a triangular sail-type blade of a wind generator using the ANSYS FLUENT software package, Technical Physics, 61, 2, 299-301.

4 Tanasheva, N.K., Kunakbaev, T.O., Dyusembaeva, A.N., Shuyushbayeva, N.N., \& Damekova S.K. (2017). Effect of a rough surface on the aerodynamic characteristics of a two-bladed wind-powered engine with cylindrical blades, Technical Physics, 62, 11, $1631-1633$.

5 Tanasheva, N.K., Dyusembaeva, A.N., \& Min'kov, L.L. (2018). Investigation of aerodynamic characteristics from the airflow angle of the rotating cylinder, Bulletin of the Karaganda University. Physics series, 1(89), 88-92. 